\title{
S2 Figure
}

A

DC
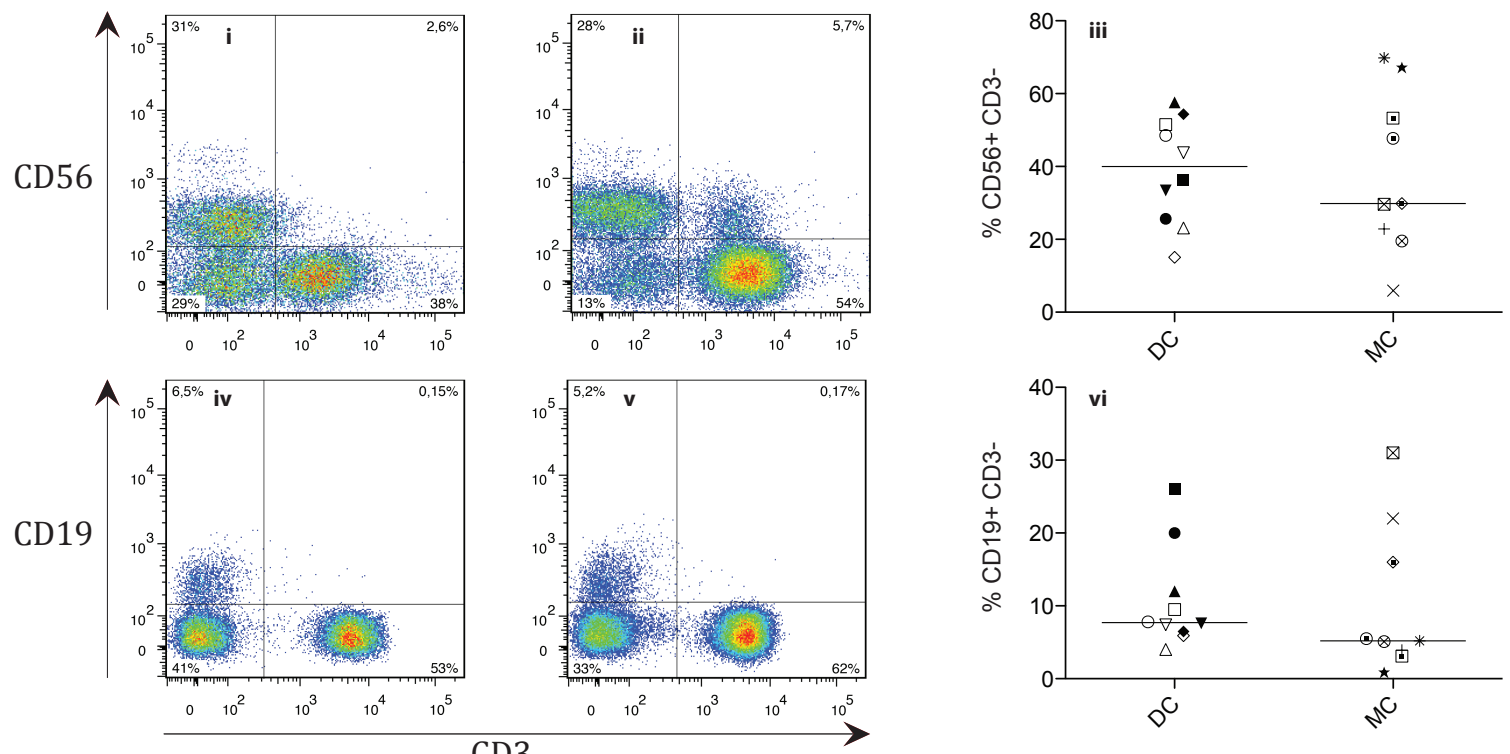

B

DC

MC
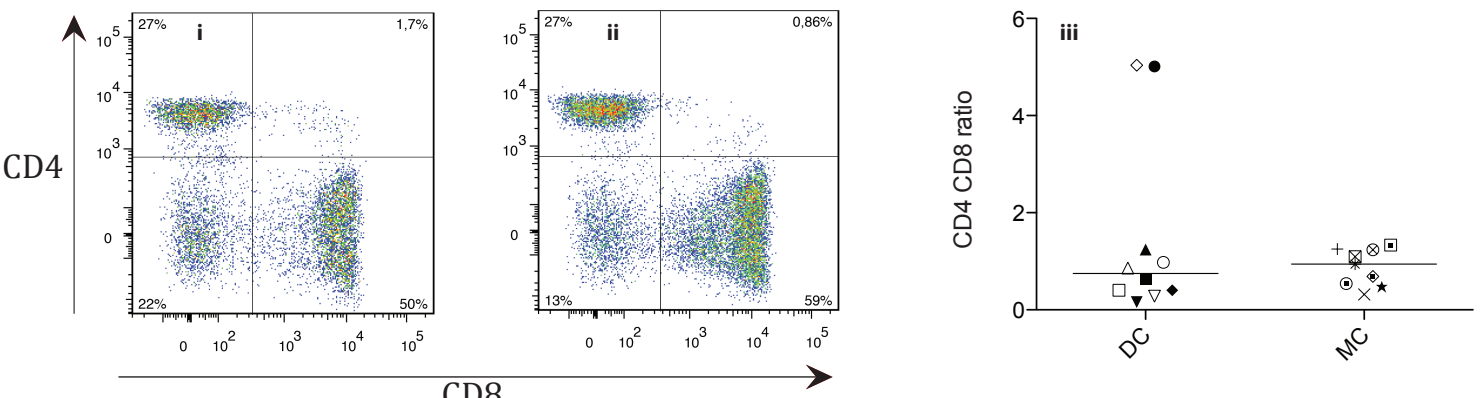